\title{
21. BIOLOGICAL MARKER SIGNIFICANCE OF ORGANIC MATTER ORIGIN IN SAPROPELS FROM THE MEDITERRANEAN RIDGE, SITE 969'1
}

\author{
Ioanna Bouloubassi, ${ }^{2}$ Guillaume Guehenneux, ${ }^{2}$ and Jürgen Rullkötter ${ }^{3}$
}

\begin{abstract}
The major extractable lipid components in a series of Pleistocene-Pliocene sapropels from Ocean Drilling Program Leg 160 Site 969 were investigated. The organic-carbon contents in sapropels of Pleistocene age have a typical range of values, up to $7.4 \%$, whereas the Pliocene sapropels were extraordinarily organic-carbon rich with values reaching $32.2 \%$. The molecular composition of extractable lipids was dominated by alkandiols and alkanolones, alkenones, and sterols, with lower amounts of $n$-alkanes and $n$-alcohols. The molecular compositions indicate that organic matter in sapropels is predominantly derived from marine algal sources. Nevertheless, the distribution of terrestrial lipids indicates a significant land-derived influx during sapropel formation.
\end{abstract}

\section{INTRODUCTION}

One of the focuses of Ocean Drilling Program Leg 160 was to investigate the origin and paleoceanographic significance of Mediterranean sapropels. These dark-colored sediment layers are rich in organic carbon, considered modern analogs of Mesozoic "black shales," which occur in young (less than $5 \mathrm{Ma}$ ) sediments, intercalated with oxidized, organic-carbon-poor hemipelagic sequences. Their deposition is thought to have occurred as a response to major climatic, hydrological, and biogeochemical changes. Since their first discovery in the 1960s, the Mediterranean sapropels (mainly those of late Pleistocene to Holocene age) have received much attention, and several scenarios, sometimes contradictory, have been proposed to explain their formation.

One hypothesis considers sapropels as the result of anoxia in Mediterranean bottom waters, which would have enhanced preservation of organic matter. This hypothesis is supported by isotopic anomalies observed in sapropels (e.g., Vergnaud-Grazzini et al., 1986) and faunal studies (Thunell et al., 1984), implying a stable density stratification of the water column. Increased continental freshwater run off, either from floods of the Nile River (Rossignol-Strick, 1985) or from increased precipitation in the northern borderlands of the Eastern Mediterranean (Rohling and Hilgen, 1991), would have caused this stratification. In both cases there would be a link to global climatic changes and to a strong change (possible reversal) of the Mediterranean circulation, which led the eastern basin to act as a nutrient trap. This, in turn, could have led to a concomitant increase of primary productivity and the associated carbon fluxes.

An alternative hypothesis postulates that enhanced productivity with a concurrent rise in the flux of organic matter to the sediments is the primary factor controlling the formation of sapropels (Calvert, 1983; Pedersen and Calvert, 1990). Using relations published by Müller and Suess (1979) and averaged values for sedimentation rates, sediment density, and porosity, Calvert (1983) concluded that anoxic conditions alone could not have been responsible for the accumulation of organic carbon reaching values as high as $20 \%$. Instead, the formation of such organic-carbon-rich layers requires that primary

${ }^{1}$ Robertson, A.H.F., Emeis, K.-C., Richter, C., and Camerlenghi, A. (Eds.), 1998. Proc. ODP, Sci. Results, 160: College Station, TX (Ocean Drilling Program).

${ }^{2}$ Département de Géologie et Océanographie, Université Bordeaux I, URA CNRS 197, avenue des Facultés, 33405 Talence cedex, France.

bouloubassi@geocean.u-bordeaux.fr

${ }^{3}$ Institut für Chemie und Biologie des Meeres (ICBM), Carl von Ossietzky Universität Oldenburg, Postfach 2503, 26111 Oldenburg, Federal Republic of Germany. productivity exceeds $500 \mathrm{gC} / \mathrm{cm}^{2} / \mathrm{yr}$, a value comparable to modern upwelling systems. Other authors have similarly concluded that organic production was substantially increased in the Eastern Mediterranean at times of sapropel formation (De Lange and ten Haven, 1983).

Recently, Rohling (1994) proposed that the formation of sapropels occurred in an anti-estuarine type of water circulation established in response to reduction of the Eastern Mediterranean excess of evaporation over freshwater supply. The described scenario accounts for most of the previously reported observations and deduced mechanisms.

The work presented herein contributes to the Leg 160 multi-proxy approach for the investigation of sapropels. It deals with the study of major free extractable lipid constituents in selected Pleistocene and Pliocene sapropels from Site 969. The data are used to assess the origin of the organic matter (marine vs. terrestrial) as well as the dominant specific biological sources.

\section{SAMPLES AND BACKGROUND INFORMATION}

Site 969 is located on the Mediterranean Ridge $\left(33^{\circ} 50.40^{\prime} \mathrm{N}\right.$ and $24^{\circ} 53.06^{\prime} \mathrm{E}$ ) at $2200 \mathrm{~m}$ water depth. Background information on Site 969 has been detailed earlier (Shipboard Scientific Party, 1996) and is summarized here.

Sedimentary Unit I of the sequence at this site consists of lower Pliocene through Holocene nannofossil oozes and nannofossil clays with over 80 sapropel beds. Based on shipboard data, these sapropels were characterized by a number of physical properties: their density was lower than that of adjacent carbonate oozes, their porosity was higher, and their gamma-ray emission was distinctly higher. The sapropels occur in five distinct groups, separated by intervals of sediment that are commonly oxidized, yellowish brown, and without preserved sapropels.

The upper group of sapropel beds comprises the typical Holocene-upper Pleistocene sequence with S1, S3, S4, S5, S6, and S7 all present. In the uppermost Pliocene to lower Pleistocene sequence, sapropels are severely affected by shearing, and several of them appear to be faulted out of the sequence. Shipboard organic-carbon determinations through this interval (samples taken from Hole 969A) record maximum values of $17.6 \%$ with a more common range of $2 \%-$ $10 \%$. Two distinctive groups of particularly black sapropel beds occurred in a gray-colored background interval of middle Pliocene age. These sapropels are extraordinarily organic-carbon rich with a maximum value of $30.5 \%$. 
$\mathrm{C}_{\mathrm{org}} / \mathrm{N}$ ratios for almost all sapropels exceeded the value of 12 with an average of 17 and a maximum of 23 . The surprisingly high values of $\mathrm{C}_{\mathrm{org}} / \mathrm{N}$ ratios could suggest a predominance of terrestrial organic matter, but this however is not in accordance with the source indications provided by Rock-Eval parameters. The high $\mathrm{C}_{\text {org }} / \mathrm{N}$ values in the sapropels are tentatively interpreted as representing an effective removal of nitrogen compounds from marine organic matter during diagenesis; however, it cannot be ruled out that the primary marine organic matter was already poor in nitrogen bearing constituents.

Results of Rock-Eval pyrolysis showed that hydrogen indices for many samples exceed $300 \mathrm{mg} \mathrm{hc} / \mathrm{g} \mathrm{C}_{\text {org }}$, with a maximum value slightly above $450 \mathrm{mg} \mathrm{hc/g} \mathrm{C}_{\text {org. }}$. The hydrogen index values indicate partial oxidation of primary marine organic matter and/or an admixture of terrigenous organic matter. Consistent with the relationship between organic matter type and elemental composition, oxygen indices show an opposite trend to the hydrogen indices. There is a general tendency for higher hydrogen indices with increasing content of organic matter. Sulfur contents were high in all sapropels, especially in those of mid-Pliocene age, where a maximum value of $13.2 \%$ was encountered and the downhole profile of total sulfur roughly paralleled that of organic carbon.

We report here data from samples from Holes 969B and 969E. They include samples from Pleistocene sapropels, namely S5 (Samples 160-969B-2H-1, 38-40 cm, and 160-969E-1H-3, 87-89 cm), S6 (Samples 160-969E-2H-1, 47-49 cm, 160-969E-2H-1, 63-65 cm, and 160-969B-2H-2, 70-72 cm) and S7 (Sample 160-969E-2H-2, $128-130 \mathrm{~cm})$.

Additionally, two multisample series were taken across the sapropel beds of mid-Pliocene age, that are the most organic-carbonrich Mediterranean sapropels recovered. Their position is at Samples 160-969B-7H-1, $96 \mathrm{~cm},(51.36 \mathrm{mbsf}, 11 \mathrm{~cm}$ thickness) and 160$969 \mathrm{~B}-7 \mathrm{H}-2,77 \mathrm{~cm}(52.67 \mathrm{mbsf}, 16 \mathrm{~cm}$ thickness $)$. In the interest of simplicity, the two Pliocene sapropels are referred to here as sapropel $\mathrm{A}$ and $\mathrm{B}$, respectively. Samples were also taken from organiccarbon-lean beds underlying and overlying those sapropels (Fig. 1).

\section{EXPERIMENTAL}

Lipids were extracted from freeze-dried sediment samples by ultrasonication with a mixture of $\mathrm{CH}_{2} \mathrm{Cl}_{2} / \mathrm{MeOH}(2: 1 \mathrm{v} / \mathrm{v})$. The supernatant solutions were recovered after centrifugation, combined, and washed with aqueous $\mathrm{KCl}$ to separate salts. Excess solvent was then removed by rotary evaporation. Separation of lipid classes was achieved by flash chromatography on silica gel, based on the procedure described in details by Stephanou and Stratigakis (1993). Nonaromatic hydrocarbons and long-chain alkenones were analyzed directly by gas chromatography, whereas hydroxyl-bearing compounds (sterols, alcohols) were first derived to their trimethylsilyl ethers (TMSi-ethers) by heating with bis(trimethylsiloxy)-trifluoroacetamide (BSTFA) for $1 \mathrm{hr}$ at $60^{\circ} \mathrm{C}$.

\section{Gas Chromatography}

Gas chromatography (GC) was carried out on a Hewlett Packard (HP) model 5890 Series II gas chromatograph fitted with a flame ionization detector, an on-column injector and a $30 \mathrm{~m} \times 0.32 \mathrm{~mm}$ (i.d.) HP-5 fused silica capillary column. Helium was used as carrier gas. The column temperature was programmed from $50^{\circ} \mathrm{C}$ to $80^{\circ} \mathrm{C}$ at $25^{\circ} \mathrm{C} / \mathrm{min}$, and then to $300^{\circ} \mathrm{C}$ at $3^{\circ} \mathrm{C} / \mathrm{min}$ for hydrocarbon analysis, from $50^{\circ} \mathrm{C}$ to $220^{\circ} \mathrm{C}$ at $25^{\circ} \mathrm{C} / \mathrm{min}$ and then to $300^{\circ} \mathrm{C}$ at $5^{\circ} \mathrm{C} / \mathrm{min}$ for alkenone analysis, from $50^{\circ} \mathrm{C}$ to $150^{\circ} \mathrm{C}$ at $10^{\circ} \mathrm{C} / \mathrm{min}$ and then to
160-969B-7H-1

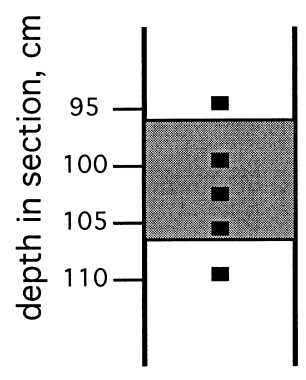

160-969B-7H-2

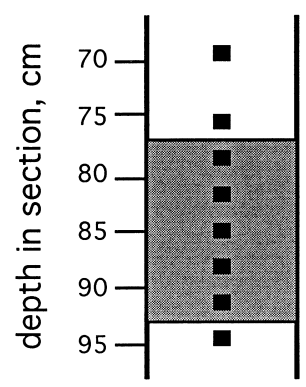

Organic C, \%
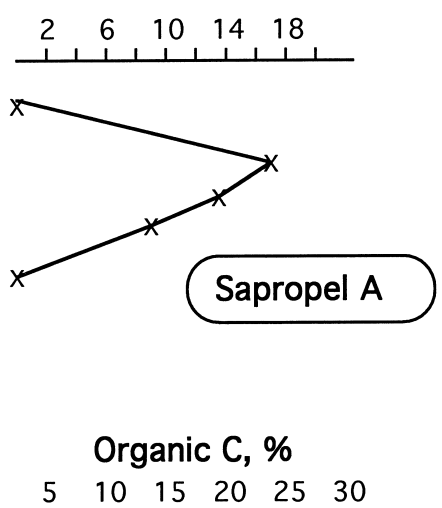

x

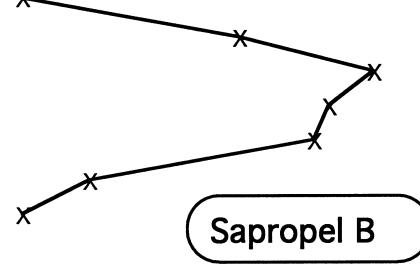

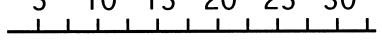

Figure 1. Location of samples in Pliocene sapropels and in organic-carbonlean sediments and profile of organic-carbon contents.

$300^{\circ} \mathrm{C}$ at $5^{\circ} \mathrm{C} / \mathrm{min}$ for the analysis of alcohols and sterols (as TMSiether derivatives).

\section{Gas Chromatography-Mass Spectrometry}

Gas Chromatography-Mass Spectrometry (GC-MS) analysis was performed on a HP Model 5890 gas chromatograph directly coupled to a HP mass-selective detector. Capillary column and temperature programming were the same as for the GC analysis. The mass spectrometer was operated in electron impact mode (ion energy $70 \mathrm{eV}$, ion source temperature $\left.200^{\circ} \mathrm{C}\right)$ with a scan time $(\mathrm{m} / \mathrm{z} 50-600)$ of $1 \mathrm{~s}$. A MS-Chemstation (HP) system was used for data acquisition and processing.

The individual lipid components were identified by a combination of GC-retention characteristics, co-injection with standards, and comparison of mass-spectral data with those in the literature. Quantitation was based on the GC-FID response and achieved by comparison of peak areas with those of known quantities of standards added to the samples either before extraction or before GC analysis.

\section{RESULTS AND DISCUSSION Organic Carbon}

The percentage of organic carbon in the Pleistocene sapropels varied from $2.5 \%$ to $7.40 \%$, with higher values for S5 and lowest for S6 (Table 1). Although high, these values are eclipsed by those of the Pliocene sapropels, in which the percentage of organic carbon reached $32.2 \%$, the highest value reported in sapropels so far. The organic carbon distribution within these sapropels was rather uniform, although a tendency for rapidly decreasing organic-carbon contents 
Table 1. Summary of hydrocarbon data.

\begin{tabular}{|c|c|c|c|c|c|c|c|c|c|c|}
\hline $\begin{array}{l}\text { Core, section, } \\
\text { interval }(\mathrm{cm})\end{array}$ & Sapropel & $\begin{array}{l}\text { Organic carbon } \\
(\%)\end{array}$ & $\begin{array}{c}n \text {-alkanes } \\
(\mu \mathrm{g} / \mathrm{g})\end{array}$ & $\begin{array}{l}n \text {-alkanes } \\
(\mu \mathrm{g} / \mathrm{g} \mathrm{C})\end{array}$ & $\begin{array}{c}\mathrm{C}_{27}-\mathrm{C}_{33} \\
(\mu \mathrm{g} / \mathrm{g})\end{array}$ & $\begin{array}{l}\mathrm{C}_{27}-\mathrm{C}_{33} \\
(\mu \mathrm{g} / \mathrm{g} \mathrm{C})\end{array}$ & $\begin{array}{c}\mathrm{C}_{27}-\mathrm{C}_{33} \\
(\%)\end{array}$ & $\begin{array}{c}\mathrm{CPI} \\
\left(\mathrm{C}_{25}-\mathrm{C}_{33}\right)\end{array}$ & $\begin{array}{l}\text { LMW/ } \\
\text { HMW }\end{array}$ & $\mathrm{C}_{\max }$ \\
\hline $\begin{array}{l}160-969 \mathrm{~B}- \\
2 \mathrm{H}-1,38-40\end{array}$ & \multirow[b]{2}{*}{ S5 } & 7.40 & 9.85 & 133.16 & 5.76 & 77.83 & 66.92 & 5.9 & 0.11 & 31 \\
\hline $\begin{array}{l}160-969 \mathrm{E}- \\
1 \mathrm{H}-3,87-89\end{array}$ & & 7.30 & 11.39 & 155.99 & 4.19 & 57.40 & 49.13 & 2.8 & 0.19 & 31 \\
\hline $\begin{array}{l}2 \mathrm{H}-1,47-49 \\
2 \mathrm{H}-1,63-65\end{array}$ & \multirow{2}{*}{ S6 } & $\begin{array}{l}2.90 \\
2.50\end{array}$ & $\begin{array}{l}5.03 \\
6.37\end{array}$ & $\begin{array}{l}173.48 \\
254.86\end{array}$ & $\begin{array}{l}2.86 \\
2.92\end{array}$ & $\begin{array}{r}98.52 \\
116.81\end{array}$ & $\begin{array}{l}69.07 \\
65.07\end{array}$ & $\begin{array}{l}4.0 \\
2.2\end{array}$ & $\begin{array}{l}0.13 \\
0.18\end{array}$ & $\begin{array}{l}31 \\
31\end{array}$ \\
\hline $\begin{array}{l}\text { 160-969B- } \\
2 \mathrm{H}-2,70-72\end{array}$ & & 3.10 & 5.17 & 166.90 & 3.26 & 105.04 & 70.77 & 6.8 & 0.14 & 31 \\
\hline $\begin{array}{l}\text { 160-969E- } \\
2 \mathrm{H}-2,128-130\end{array}$ & S7 & 5.50 & 7.06 & 128.45 & 3.51 & 63.76 & 68.58 & 2.5 & 0.17 & 31 \\
\hline $\begin{array}{c}\text { 160-969B- } \\
7 \mathrm{H}-1,94-95 \\
7 \mathrm{H}-1,99-100 \\
7 \mathrm{H}-1,102-103 \\
7 \mathrm{H}-1,105-106 \\
7 \mathrm{H}-1,109-110 \\
\end{array}$ & $\begin{array}{c}\text { Sapropel } \\
\text { A }\end{array}$ & $\begin{array}{r}0.16 \\
16.50 \\
13.62 \\
9.10 \\
0.15 \\
\end{array}$ & $\begin{array}{r}0.89 \\
18.16 \\
15.36 \\
11.22 \\
0.81 \\
\end{array}$ & $\begin{array}{l}556.83 \\
110.04 \\
112.78 \\
123.26 \\
538.29 \\
\end{array}$ & $\begin{array}{r}0.64 \\
11.69 \\
9.87 \\
6.49 \\
0.56 \\
\end{array}$ & $\begin{array}{r}397.55 \\
70.86 \\
72.50 \\
71.32 \\
376.66 \\
\end{array}$ & $\begin{array}{l}78.97 \\
73.61 \\
73.53 \\
66.42 \\
77.26 \\
\end{array}$ & $\begin{array}{l}7.8 \\
6.2 \\
6.2 \\
6.0 \\
7.9 \\
\end{array}$ & $\begin{array}{l}0.12 \\
0.15 \\
0.17 \\
0.20 \\
0.16 \\
\end{array}$ & $\begin{array}{l}31 \\
31 \\
31 \\
31 \\
31 \\
\end{array}$ \\
\hline $\begin{array}{l}7 \mathrm{H}-2,68-70 \\
7 \mathrm{H}-2,75-76 \\
7 \mathrm{H}-2,80-81 \\
7 \mathrm{H}-2,83-84 \\
7 \mathrm{H}-2,85-86 \\
7 \mathrm{H}-2,88-89 \\
7 \mathrm{H}-2,90-91 \\
7 \mathrm{H}-2,94-95\end{array}$ & $\begin{array}{l}\text { Sapropel } \\
\text { B }\end{array}$ & \begin{tabular}{r|}
0.17 \\
1.80 \\
21.70 \\
32.20 \\
28.30 \\
27.40 \\
8.90 \\
0.19
\end{tabular} & \begin{tabular}{r|}
1.20 \\
3.10 \\
30.68 \\
37.04 \\
38.20 \\
29.83 \\
7.23 \\
0.71
\end{tabular} & $\begin{array}{r}705.88 \\
171.96 \\
141.36 \\
115.04 \\
134.98 \\
108.88 \\
81.20 \\
376.29\end{array}$ & $\begin{array}{r}0.98 \\
2.09 \\
18.39 \\
21.90 \\
20.44 \\
17.31 \\
4.09 \\
0.48\end{array}$ & $\begin{array}{r}576.47 \\
115.98 \\
84.73 \\
68.00 \\
72.21 \\
63.16 \\
46.01 \\
251.11\end{array}$ & $\begin{array}{l}81.67 \\
77.19 \\
70.25 \\
67.87 \\
62.00 \\
67.94 \\
67.03 \\
74.51\end{array}$ & $\begin{array}{l}8.1 \\
6.1 \\
5.4 \\
6.2 \\
5.8 \\
5.5 \\
5.0 \\
7.0\end{array}$ & $\begin{array}{l}0.14 \\
0.10 \\
0.15 \\
0.16 \\
0.20 \\
0.15 \\
0.13 \\
0.17\end{array}$ & $\begin{array}{l}31 \\
31 \\
31 \\
31 \\
31 \\
31 \\
31 \\
31\end{array}$ \\
\hline
\end{tabular}

Notes: $\mathrm{C}_{27}-\mathrm{C}_{33}=$ sum of $n$-alkanes with $27,29,31$, and 33 carbon atoms. LMW/HMW $=$ ratio of the sum of low MW n-alkanes $\left(\mathrm{C}_{15}-\mathrm{C}_{23}\right)$ vs. the sum of high MW n-alkanes $\left(\mathrm{C}_{25}-\mathrm{C}_{33}\right)$.

$\mathrm{CPI}=\left(\mathrm{C}_{25}-\mathrm{C}_{33}\right)=$ carbon Preference Index in the range $\mathrm{C}_{25}-\mathrm{C}_{33}$. $\mathrm{C}_{\max }=$ carbon number of the most abundant $n$-alkane.

can be observed towards the end of the sapropel episode (Fig. 1). Oxidized sediments above and below the sapropels showed the typical background values of organic carbon, not exceeding $0.19 \%$. These results are very similar to those obtained from shipboard analysis of coeval sapropels from Hole 969A.

\section{Hydrocarbons}

A series of $n$-alkanes ranging from $n-\mathrm{C}_{15}$ to $n-\mathrm{C}_{37}$ were the major non aromatic hydrocarbons detected in almost all samples. Their distributions are dominated by long-chain $\left(\mathrm{C}_{25}-\mathrm{C}_{35}\right)$ homologs with $n$ $\mathrm{C}_{31}$ as the most abundant member (Fig. 2). Their total concentrations were variable; they ranged from 5.03 to $11.4 \mu \mathrm{g} / \mathrm{g}$ dry weight (d.w.) in Pleistocene sapropels and were higher, up to $38.20 \mu \mathrm{g} / \mathrm{g}$ d.w., in Pliocene sapropels, whereas they remained low, less than $1 \mu \mathrm{g} / \mathrm{g} \mathrm{d}$.w., in nonsapropel sediments (Table 1). The contributions of $n$-alkanes to the organic carbon (concentrations expressed as $\mu \mathrm{g} / \mathrm{g} \mathrm{C}$ ) were less variable and showed maximum values in nonsapropel samples (Table 1).

The compositional features of $n$-alkanes were virtually identical for both Pleistocene and Pliocene sapropels (Fig. 2). Furthermore, organic-carbon-lean sequences below and above sapropels were characterized by the same $n$-alkane mixture. The predominant long-chain $n$-alkanes showed a strong odd-over-even carbon number predominance, reflected in high CPI values of 2.2-6.8 and 5.4-7.9 in Pleistocene and Pliocene sapropels, respectively (Table 1). Such distributions are characteristic of higher plant cuticles (Eglinton and Hamilton, 1967) and can be used to trace supply of terrigenous organic matter. $n$-Alkanes from marine sources tend to be of relatively shortchain length, notably $C_{15}$ and $C_{17}$ (Blumer et al., 1971). Within the studied sections $n$-alkanes with such a carbon chain length were very minor. The ratio of short- $\left(\mathrm{C}_{15}-\mathrm{C}_{23}\right)$ to long- $\left(\mathrm{C}_{25}-\mathrm{C}_{35}\right)$ chain alkanes remained very low, $0.1-0.2$, in all samples (Table 1 ).

Consequently, the $n$-alkane series seem to indicate a strong terrigenous contribution of hydrocarbons to the organic matter. However,

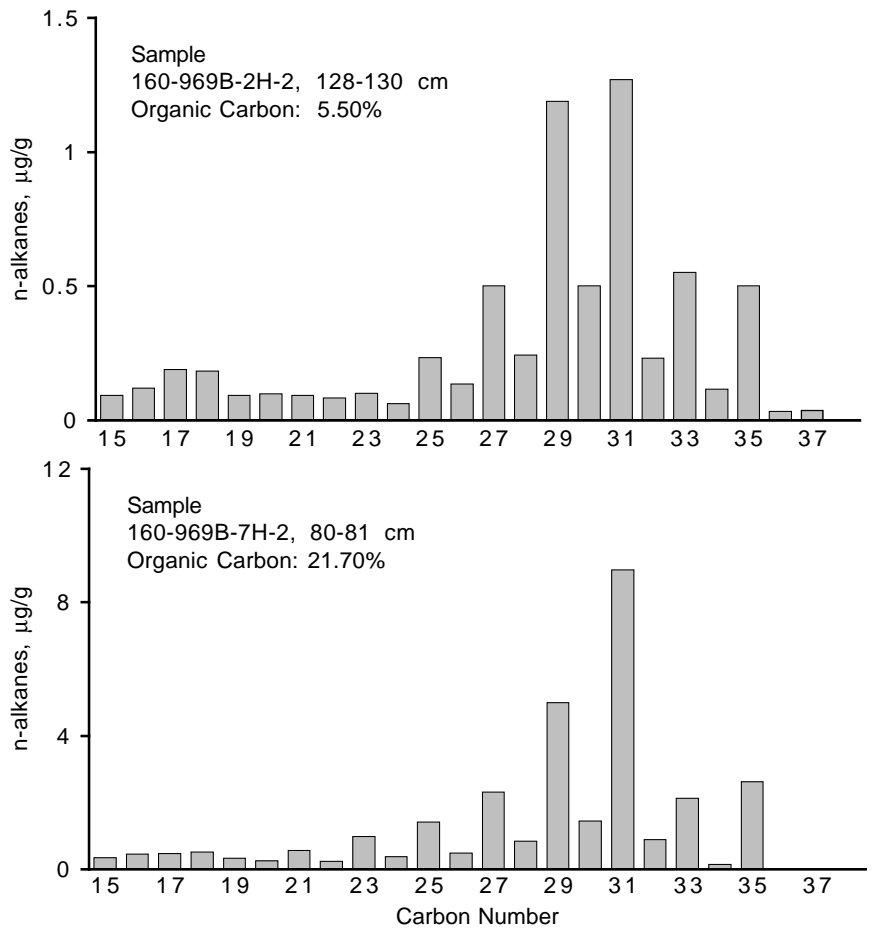

Figure 2. Representative $n$-alkane profiles in Pleistocene (Sample 160-969B$2 \mathrm{H}-2,128-130 \mathrm{~cm}$ ) and Pliocene (Sample 160-969B-7H-2, 80-81 cm) sapropel samples. 
this class of compounds alone cannot be used to estimate the relative amount of terrigenous vs. marine organic matter in the sediments because biogenic sources other than higher land plants do not contribute major quantities of $n$-alkanes. Furthermore, short-chain, marine $n$ alkanes are considered to be much more labile than the long-chain homologs.

A series of compounds eluting between the $n-\mathrm{C}_{20}$ and $n-\mathrm{C}_{21}$ alkanes under the GC conditions used here were often among the major constituents of the nonaromatic hydrocarbon fraction. Their mass spectra and retention time characteristics are similar but not identical to those reported for $\mathrm{C}_{25}$ highly branched isoprenoids (Requejo et al., 1984; Venkatesan, 1988). Such isoprenoid compounds have been reported in a variety of marine regions (Rowland and Robson, 1990) and considered to derive mainly from diatoms (Volkman et al., 1984). In the present study these hydrocarbons occurred in low levels in the investigated Pleistocene sapropel samples, whereas they were dominant in Pliocene sapropels with concentrations as high as 34.5 $\mu \mathrm{g} / \mathrm{g}$. They were not detected in organic-carbon-lean samples overlying and underlying sapropels. According to initial structure elucidation most of these compounds may be novel dicyclic hydrocarbons (Rullkötter et al., Chap. 22, this volume).

\section{n-Alcohols}

All samples contained a series of $n$-alkan-1-ols, ranging from $\mathrm{C}_{16}$ to $\mathrm{C}_{32}$ and dominated by components with more than 20 carbon atoms, with $n-\mathrm{C}_{28}$ as the most abundant homolog (Fig. 3). Their concentrations spanned a large range (Table 2), varying from 4.46 to $16.84 \mu \mathrm{g} / \mathrm{g}$ in the sapropels of Pleistocene age, and on even larger range in the Pliocene sapropels, $(4.54-70.43 \mu \mathrm{g} / \mathrm{g})$. In contrast, the $n$ alcohol concentrations were very low (less than $1.84 \mu \mathrm{g} / \mathrm{g}$ ) in Pliocene samples overlying and underlying the sapropels. The alcohol abundance normalized to organic carbon did not exhibit the same trend, since these values were similar in all the sapropel samples and remarkably higher in the underlying and overlying sediments (Table 2).

The predominance of long-chain homologs $\left(\mathrm{C}_{26}-\mathrm{C}_{32}\right)$ and the very high even-over-odd carbon number preference of the $n$-alcohols are characteristic of terrigenous organic matter from higher plants, where they mainly occur as wax esters (Eglinton and Hamilton, 1967). Their high abundance as free lipids in the sapropels can be explained by hydrolysis of wax esters during diagenesis in sediments. The series of $n$-alkanols clearly indicates a large terrigenous lipid contribution to the organic matter, as also seen in the $n$-alkanes. However, as it was already stressed for the $n$-alkanes, these indications can not be interpreted without comparison with lipids specific of marine sources, because the latter sources are poorly represented in the $n$-alkane and $n$ alcohol series.

It is noteworthy that the increase of long-chain $n$-alcohols concentrations within sapropels A and B is much greater than that of longchain $n$-alkanes (Fig. 4). It appears that the relative abundance of alcohols compared to alkanes rapidly increases with increasing organic-carbon content. Since alcohols are known to be more labile than alkanes, this most likely indicates conditions of enhanced preservation prevailing during sapropel formation.

Most of the sapropel samples also contained substantial quantities of monounsaturated $n$-alcohols in the range $\mathrm{C}_{22}-\mathrm{C}_{32}$ (not shown here). These alkenols were virtually absent in the organic-carbonlean sediments underlying and overlying sapropels. Their origin is still not clear. $\mathrm{C}_{22: 1}-\mathrm{C}_{26: 1}$ alcohols have been ascribed both to a terrigenous origin (Gaskell et al., 1975) and to bacterial reduction of unsaturated fatty acids. They have also been reported in some marine zooplankton $\left(\mathrm{C}_{20: 1}-\mathrm{C}_{26: 1}\right)$, but as trace constituents (Sargent et al., 1981). $C_{22: 1}, C_{24: 1}$, and $C_{26: 1}$ alcohols have been previously reported by Smith et al., (1986) and ten Haven et al., (1987) for Pleistocene sapropels (S1 and S7). In the cited studies, unsaturated alcohols were detected in lipid extracts after alkaline hydrolysis, which means that

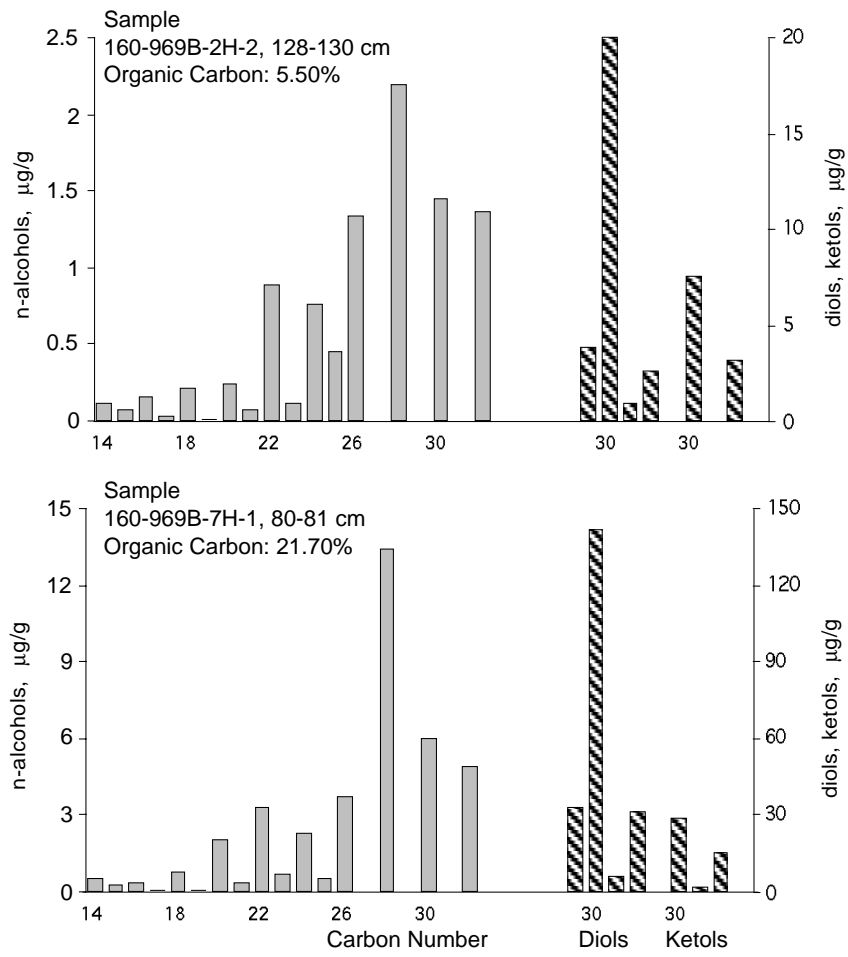

Figure 3. Representative $n$-alcohol and diol/ketol profiles in Pleistocene (Sample 160-969B-2H-2, 128-130 cm) and Pliocene (Sample 160-969B-7H$2,80-81 \mathrm{~cm}$ ) sapropel samples.

they occurred mainly as esterified moieties. It is noteworthy that in the present study unsaturated alcohols occurred as free, nonsaponified lipids and showed a wider range of carbon numbers, up to $\mathrm{C}_{32}$.

Phytol, a typical marine isoprenoid alcohol, was either not detected or present at trace levels, unlike the findings of previous reports on sapropels (Smith et al., 1986; ten Haven et al., 1987). This again highlights the importance of the mode of occurrence of the various organic compounds, because phytol occurred mainly in an esterified form, like the unsaturated alcohols, and in the present study no hydrolysis step was included. Apparently hydrolysis during diagenesis did not release phytol as it did for alcohols derived from higher plant wax esters.

\section{Alkandiols, Alkanolones (Ketols)}

Along with the high abundance of long-chain terrestrial $n$-alcohols, the alcohol fraction was dominated by a series of long-chain alkandiols $\left(\mathrm{C}_{28}, \mathrm{C}_{30}, \mathrm{C}_{31}\right.$, and $\left.\mathrm{C}_{32}\right)$ and alkanolones $\left(\mathrm{C}_{30}, \mathrm{C}_{31}\right.$, and $\left.\mathrm{C}_{32}\right)$ (Fig. 3). Odd-carbon-numbered homologs were minor and in most cases were detected at trace levels. In all samples analyzed, the $\mathrm{C}_{30}$ compound was the most abundant and accompanied by smaller amounts of $\mathrm{C}_{28}$ and $\mathrm{C}_{32}$ homologs.

Alkandiols were among the most abundant lipid constituents identified in the sapropels. Their concentrations varied from 4.8 to $103.4 \mu \mathrm{g} / \mathrm{g}$ in Pleistocene sapropels, and they were even more abundant (up to $297.9 \mu \mathrm{g} / \mathrm{g}$ ) in Pliocene sapropels (Table 2). Alkanolones generally occurred in much lower abundance $(1.93-27.14 \mu \mathrm{g} / \mathrm{g}$ and $3.34-73.68 \mu \mathrm{g} / \mathrm{g}$ in Pleistocene and Pliocene sapropels, respectively). The alkandiol and alkanolone concentration normalized to organic carbon exhibited very high values; alkandiols reached $1052.6 \mu \mathrm{g} / \mathrm{g} \mathrm{C}$ in sample 160-969B-7H-2, 90-91 cm.

Since their first identification in Holocene Black Sea Unit 1 and Unit 2 sediments (de Leeuw et al., 1981), the occurrence of longchain alkandiols and alkanolones has subsequently been reported in 
Table 2. Summary of alcohol data.

\begin{tabular}{|c|c|c|c|c|c|c|c|c|c|c|}
\hline $\begin{array}{l}\text { Core, section, } \\
\text { interval }(\mathrm{cm})\end{array}$ & Sapropel & $\begin{array}{l}n \text {-alcohols } \\
(\mu \mathrm{g} / \mathrm{g})\end{array}$ & $\begin{array}{c}n \text {-alcohols } \\
(\mu \mathrm{g} / \mathrm{g} \mathrm{C})\end{array}$ & $\begin{array}{c}\mathrm{C}_{24}-\mathrm{C}_{32} \\
(\mu \mathrm{g} / \mathrm{g})\end{array}$ & $\begin{array}{l}\mathrm{C}_{24}-\mathrm{C}_{32} \\
(\mu \mathrm{g} / \mathrm{g} \mathrm{C})\end{array}$ & $\begin{array}{c}\mathrm{C}_{24}-\mathrm{C}_{32} \\
(\%)\end{array}$ & $\begin{array}{l}\text { LMW/ } \\
\text { HMW }\end{array}$ & $\mathrm{C}_{\max }$ & $\begin{array}{c}\mathrm{C}_{28}-\mathrm{C}_{32} \\
\text { diols } \\
(\mu \mathrm{g} / \mathrm{g})\end{array}$ & $\begin{array}{c}\mathrm{C}_{30}-\mathrm{C}_{32} \\
\text { ketols } \\
(\mu \mathrm{g} / \mathrm{g})\end{array}$ \\
\hline $\begin{array}{l}\text { 160-969B- } \\
2 \mathrm{H}-1,38-40\end{array}$ & S5 & 16.84 & 227.62 & 8.22 & 111.13 & 48.82 & 0.72 & 28 & 103.37 & 27.14 \\
\hline $\begin{array}{l}160-969 \mathrm{E}- \\
1 \mathrm{H}-3,87-89 \\
\end{array}$ & 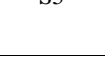 & 13.18 & 180.48 & 9.14 & 125.22 & 69.38 & 0.38 & 28 & 5.46 & 8.05 \\
\hline $\begin{array}{l}2 \mathrm{H}-1,47-49 \\
2 \mathrm{H}-1,63-65\end{array}$ & S6 & $\begin{array}{l}4.46 \\
6.14\end{array}$ & $\begin{array}{l}153.77 \\
245.60\end{array}$ & $\begin{array}{l}2.76 \\
4.39\end{array}$ & $\begin{array}{r}95.28 \\
175.77\end{array}$ & $\begin{array}{l}61.96 \\
71.57\end{array}$ & $\begin{array}{l}0.56 \\
0.34\end{array}$ & $\begin{array}{l}28 \\
28\end{array}$ & $\begin{array}{l}7.87 \\
4.77\end{array}$ & $\begin{array}{l}3.80 \\
1.93\end{array}$ \\
\hline $\begin{array}{l}160-969 \mathrm{~B}- \\
2 \mathrm{H}-2,70-72 \\
\end{array}$ & & 5.12 & 165.08 & 3.50 & 112.86 & 68.37 & 0.29 & 28 & 7.53 & 2.17 \\
\hline $\begin{array}{l}160-969 \mathrm{E}- \\
2 \mathrm{H}-2,128-130 \\
\end{array}$ & S7 & 9.42 & 171.24 & 7.09 & 128.89 & 75.27 & 0.25 & 28 & 27.37 & 10.71 \\
\hline $\begin{array}{l}\text { 160-969B- } \\
7 \mathrm{H}-1,94-95 \\
7 \mathrm{H}-1,99-100 \\
7 \mathrm{H}-1,102-103 \\
7 \mathrm{H}-1,105-106 \\
7 \mathrm{H}-1,109-110\end{array}$ & $\begin{array}{c}\text { Sapropel } \\
\text { A }\end{array}$ & $\begin{array}{r}0.41 \\
40.55 \\
28.40 \\
14.19 \\
0.35\end{array}$ & $\begin{array}{l}253.26 \\
245.74 \\
208.52 \\
155.97 \\
231.68\end{array}$ & $\begin{array}{r}0.37 \\
31.84 \\
21.97 \\
11.35 \\
0.32\end{array}$ & $\begin{array}{l}230.00 \\
192.96 \\
161.29 \\
124.67 \\
210.28\end{array}$ & $\begin{array}{l}90.81 \\
78.52 \\
77.35 \\
79.94 \\
90.76\end{array}$ & $\begin{array}{l}0.06 \\
0.22 \\
0.24 \\
0.21 \\
0.08\end{array}$ & $\begin{array}{l}28 \\
28 \\
28 \\
28 \\
28\end{array}$ & $\begin{array}{l}0.05 \\
92.60 \\
50.26 \\
25.02 \\
\text { ND }\end{array}$ & $\begin{array}{c}\text { ND } \\
43.72 \\
34.98 \\
15.71 \\
\text { ND }\end{array}$ \\
\hline $\begin{array}{l}7 \mathrm{H}-2,68-70 \\
7 \mathrm{H}-2,75-76 \\
7 \mathrm{H}-2,80-81 \\
7 \mathrm{H}-2,83-84 \\
7 \mathrm{H}-2,85-86 \\
7 \mathrm{H}-2,88-89 \\
7 \mathrm{H}-2,90-91 \\
7 \mathrm{H}-2,94-95\end{array}$ & $\begin{array}{c}\text { Sapropel } \\
\text { B }\end{array}$ & $\begin{array}{r}0.72 \\
4.54 \\
39.06 \\
69.39 \\
70.43 \\
50.64 \\
20.89 \\
1.84\end{array}$ & $\begin{array}{l}423.53 \\
252.21 \\
179.98 \\
215.51 \\
248.87 \\
184.83 \\
234.67 \\
966.55\end{array}$ & $\begin{array}{r}0.69 \\
3.47 \\
30.30 \\
55.71 \\
56.60 \\
42.42 \\
16.07 \\
1.59\end{array}$ & $\begin{array}{l}405.88 \\
193.02 \\
139.63 \\
173.00 \\
200.00 \\
154.81 \\
180.57 \\
839.31\end{array}$ & $\begin{array}{l}90.89 \\
76.53 \\
77.58 \\
80.28 \\
80.36 \\
83.76 \\
76.95 \\
86.84\end{array}$ & $\begin{array}{l}0.07 \\
0.27 \\
0.25 \\
0.21 \\
0.21 \\
0.16 \\
0.25 \\
0.09\end{array}$ & $\begin{array}{l}28 \\
28 \\
28 \\
28 \\
28 \\
28 \\
28 \\
28\end{array}$ & $\begin{array}{c}\text { ND } \\
17.82 \\
211.68 \\
279.88 \\
297.89 \\
180.78 \\
21.20 \\
\text { ND }\end{array}$ & $\begin{array}{l}\text { ND } \\
3.34 \\
44.72 \\
65.95 \\
73.68 \\
45.13 \\
16.23 \\
\text { ND }\end{array}$ \\
\hline
\end{tabular}

Notes: $\mathrm{C}_{24}-\mathrm{C}_{32}=$ sum of $n$-alcohols with $24,26,28,30,32$ carbon atoms. LMW/HMW $=$ ratio of the sum of low MW $n$-alcohols $\left(\mathrm{C}_{14}-\mathrm{C}_{22}\right)$ vs. the sum of high MW $n$-alcohols $\left(\mathrm{C}_{2}-\right.$ $\mathrm{C}_{32}$ ). $\mathrm{C}_{\max }=$ carbon number of the most abundant $n$-alcohol. $\mathrm{C}_{28}-\mathrm{C}_{30}$ diols $=$ sum of alkandiols with $28,30,31$, and 32 carbon atoms. $\mathrm{C}_{30}-\mathrm{C}_{32}$ ketols $=$ sum of ketols with 30,31 , and 32 carbon atoms. ND $=$ not detected.

several Holocene marine sediments (e.g. Morris and Brassell, 1988) and in high productivity areas such as upwellings (Volkman et al., 1983).

Despite their widespread occurrence as major lipid constituents, the precise biological source of alkandiols and alkanolones remains unclear. Morris and Brassell (1988) suggested that $\mathrm{C}_{30}-\mathrm{C}_{32}$ alkandiols are characteristic of cyanobacteria, based on the identification of the compounds in a plankton sample dominated by cyanobacteria (Aphanizomenon flos-aquae). However, these compounds were not detected in a culture of Aphanizomenon flos-aquae (de Leeuw et al., 1992). Alkandiols are now thought to derive from microalgae of the class Eustigmatophyceae (Volkman et al., 1992). However, several differences exist between the lipid distributions in the biota and in sediments. From the existing evidence, microalgae appear to be the most probable source of these compounds, but further studies are needed to certify the precise sources of these compounds.

In the present study, the mass spectra of the TMSi-ether derivatives of the alkandiols revealed the occurrence of several isomers that did not separate under the GC conditions used. The $\mathrm{C}_{30}$ alkandiols consisted of 1,15-, 1,14-, and 1,13-isomers as shown by ion pairs in the mass spectra at m/z 387 and 313, 373 and 327, and 341 and 359, respectively. The 1,15-diol was the most abundant isomer. The $\mathrm{C}_{28}$ homolog consisted of 1,14-, 1,13-, and 1,12-isomers (m/z 373 and 299,359 and 313 , and 327 and 345 ), with the $1,12-\mathrm{C}_{28}$ diol the dominant isomer, whereas only the 1,15 -isomer was detected for the $\mathrm{C}_{32}$ alkandiols (m/z 341 and 387) and the $\mathrm{C}_{31}$ alkandiols (m/z 327 and 387). Two major alkanolone homologs were detected, namely $C_{30}$ and $\mathrm{C}_{32}$ alkan-15-on-1-ols, with minor amounts of the $\mathrm{C}_{31}$ alkan-15on-1-ol. Additionally, the unsaturated $\mathrm{C}_{32: 1}$ alkan-15-on-1-ol was detected in most samples.

The diverse compositions of alkandiols and alkanolones found in the Pleistocene and Pliocene sapropels are very similar to those reported for sapropel S1 by Smith et al., (1986).

\section{Long-Chain Alkenones}

Long-chain $\left(\mathrm{C}_{37}-\mathrm{C}_{39}\right)$ di- and tri- (and in some cases tetra-) unsaturated methyl and ethyl ketones, commonly termed as alkenones,
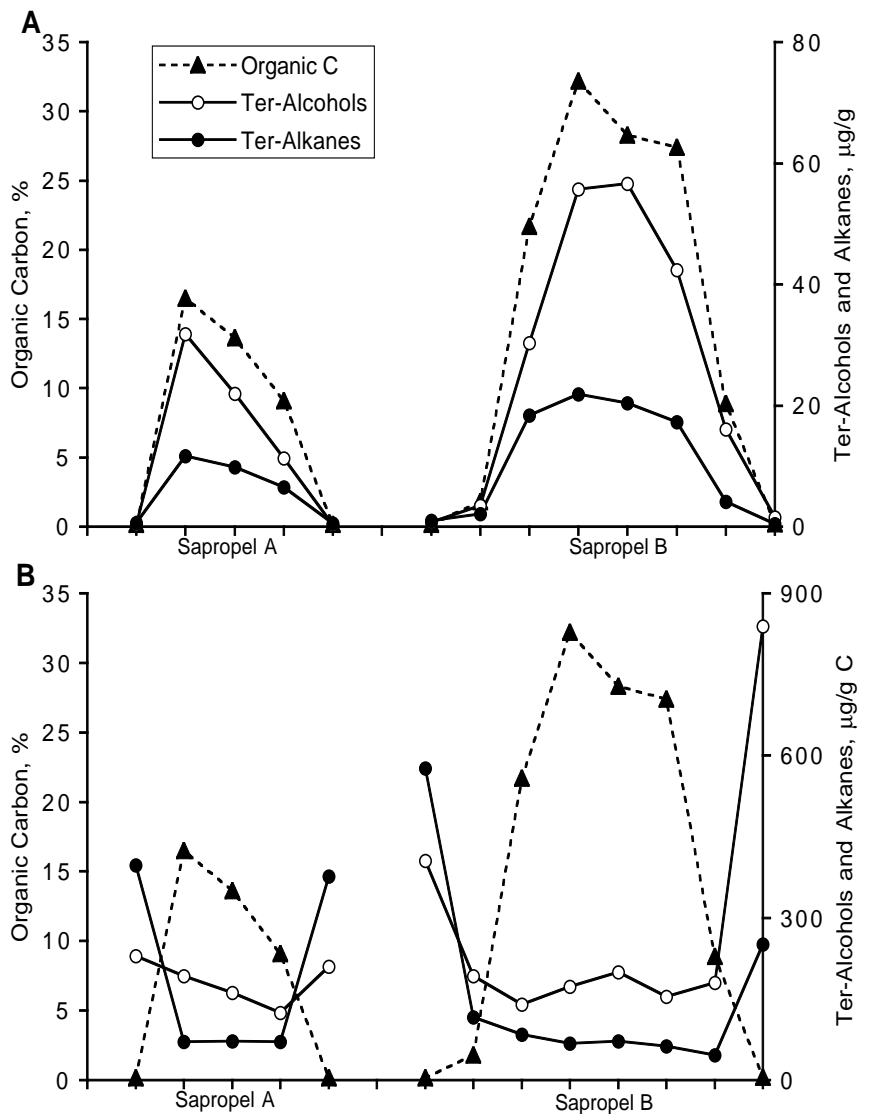

Figure 4. Distribution of terrestrial lipids within the two Pliocene sapropels. A. Profile of concentrations ( $\mu \mathrm{g} / \mathrm{g}$ of sediment). B. Profile of organic-carbonnormalized concentrations ( $\mu \mathrm{g} / \mathrm{g}$ of carbon). 
Table 3. Summary of alkenone data.

\begin{tabular}{|c|c|c|c|c|c|}
\hline $\begin{array}{l}\text { Core, section, } \\
\text { interval }(\mathrm{cm})\end{array}$ & Sapropel & $\begin{array}{c}\mathrm{C}_{37} \\
(\mu \mathrm{g} / \mathrm{g})\end{array}$ & $\begin{array}{c}\mathrm{C}_{38} \\
(\mu \mathrm{g} / \mathrm{g})\end{array}$ & $\begin{array}{c}\mathrm{C}_{39} \\
(\mu \mathrm{g} / \mathrm{g})\end{array}$ & $\begin{array}{c}\text { Sum } C_{37}-C_{39} \\
(\mu \mathrm{g} / \mathrm{g} \mathrm{C})\end{array}$ \\
\hline $\begin{array}{l}\text { 160-969B- } \\
2 \mathrm{H}-1,38-40\end{array}$ & & 7.56 & 4.13 & 0.17 & 160.32 \\
\hline $\begin{array}{l}160-969 \mathrm{E}- \\
1 \mathrm{H}-3,87-89 \\
\end{array}$ & S5 & 15.51 & 17.86 & 2.59 & 492.62 \\
\hline $\begin{array}{l}2 \mathrm{H}-1,47-49 \\
2 \mathrm{H}-1,63-65\end{array}$ & S6 & $\begin{array}{l}1.06 \\
6.46\end{array}$ & $\begin{array}{l}4.34 \\
7.65\end{array}$ & $\begin{array}{l}0.97 \\
1.17\end{array}$ & $\begin{array}{l}219.91 \\
611.21\end{array}$ \\
\hline $\begin{array}{l}\text { 160-969B- } \\
2 \mathrm{H}-2,70-72 \\
\end{array}$ & & 12.60 & 13.92 & 2.11 & 923.48 \\
\hline $\begin{array}{l}160-969 \mathrm{E}- \\
2 \mathrm{H}-2,128-130 \\
\end{array}$ & S7 & 15.22 & 16.00 & 2.26 & 608.63 \\
\hline $\begin{array}{c}\text { 160-969B- } \\
7 \mathrm{H}-1,94-95 \\
7 \mathrm{H}-1,99-100 \\
7 \mathrm{H}-1,102-103 \\
7 \mathrm{H}-1,105-106 \\
7 \mathrm{H}-1,109-110\end{array}$ & $\begin{array}{c}\text { Sapropel } \\
\text { A }\end{array}$ & $\begin{array}{r}0.02 \\
59.25 \\
59.71 \\
37.32 \\
\text { ND }\end{array}$ & $\begin{array}{r}0.02 \\
54.81 \\
49.25 \\
29.41 \\
\text { ND }\end{array}$ & $\begin{array}{l}0.00 \\
6.79 \\
5.48 \\
3.18 \\
\text { ND }\end{array}$ & $\begin{array}{c}30.01 \\
732.45 \\
840.22 \\
768.22 \\
\text { ND }\end{array}$ \\
\hline $\begin{array}{l}7 \mathrm{H}-2,68-70 \\
7 \mathrm{H}-2,75-76 \\
7 \mathrm{H}-2,80-81 \\
7 \mathrm{H}-2,83-84 \\
7 \mathrm{H}-2,85-86 \\
7 \mathrm{H}-2,88-89 \\
7 \mathrm{H}-2,90-91 \\
7 \mathrm{H}-2,94-95\end{array}$ & $\begin{array}{l}\text { Sapropel } \\
\text { B }\end{array}$ & $\begin{array}{l}\text { ND } \\
6.62 \\
92.96 \\
89.58 \\
141.40 \\
120.95 \\
27.52 \\
\text { ND }\end{array}$ & $\begin{array}{c}\text { ND } \\
5.92 \\
80.66 \\
108.44 \\
124.52 \\
78.23 \\
26.02 \\
\text { ND }\end{array}$ & $\begin{array}{c}\text { ND } \\
0.68 \\
9.85 \\
15.62 \\
15.84 \\
7.28 \\
3.04 \\
\text { ND }\end{array}$ & $\begin{array}{l}\text { ND } \\
734.62 \\
845.48 \\
663.46 \\
995.62 \\
753.51 \\
635.82 \\
\text { ND }\end{array}$ \\
\hline
\end{tabular}

Notes: $\mathrm{C}_{37}=$ sum of 37:2 methyl, 37:3 methyl, and 37:4 methyl alkenones. $\mathrm{C}_{38}=$ sum of 38:2 methyl, 38:2 ethyl, 38:3 methyl, and 38:3 ethyl alkenones. $C_{39}=$ sum of 39:2 ethyl and 39:3 ethyl alkenones. ND = not detected.

were also among the most abundant molecular constituents of the free lipid extracts. In contrast, they were virtually absent, or detected only at trace levels, in samples with very low organic contents, taken from sediment underlying and overlying sapropels. Their total concentrations ranged from 6.38 to $35.96 \mu \mathrm{g} / \mathrm{g}$ in Pleistocene sapropels and were significantly higher in the Pliocene samples where they reached $281.76 \mu \mathrm{g} / \mathrm{g}$ (Table 3 ). With the exception of samples corresponding to $\mathrm{S} 6$ sapropel, the $\mathrm{C}_{37}$ diunsaturated methyl ketone $\left(\mathrm{C}_{37: 2} \mathrm{Me}\right)$ was the major homolog, accounting for $113.47 \mu \mathrm{g} / \mathrm{g}$ in Sample 160-969B$7 \mathrm{H}-2,85-86 \mathrm{~cm}$. The summed organic-carbon-normalized concentrations of alkenones showed less pronounced variations between the Pleistocene and Pliocene sapropels than the absolute concentrations.

Since the initial discovery of long-chain alkenones in marine sediments (Boon et al., 1978), their range of occurrence has been found to encompass all the oceans (see review by Brassell, 1993). Their known biological precursor are planktonic species belonging to the Prymnesiophyceae, especially the coccolithophorid alga Emiliania huxleyi (Volkman et al., 1980), which is widely distributed in the world's oceans. The long-chain alkenones have also been identified in other members of the Prymnesiophytes, and appear to be biochemically restricted to this class of organisms (Marlowe et al., 1984).

Coccolithophorid algal fossils are abundant in sapropels, hence they are a likely source for the alkenones. Although the high abundance of alkenones in Quaternary sapropels can be explained by a contribution from Emiliania huxleyi, this can not be the case for Pliocene sapropels that extend beyond the fossil record of Emiliania huxleyi, its first occurrence being dated at ca. $268 \mathrm{ka}$ (Thierstein et al., 1977). Alkenones in pre-Pleistocene sediments have already been reported by Marlowe et al. (1990), and their occurrence is attributed to Prymnesiophytes, either coccolithophorids or other species not bearing coccoliths, but not necessarily exclusive to Emiliania huxleyi.

\section{Sterols}

Sterols were abundant in all sapropel samples. Their carbon number ranged from 26 to 30 , and their structures included nuclear unsaturated stenols and their saturated stanol counterparts, various com- pounds with unsaturated and saturated side chains, as well as both 4methyl and 4-desmethyl nuclei. Total sterol concentrations vary from 3.05 to $24.18 \mu \mathrm{g} / \mathrm{g}$ in Pleistocene sapropels, whereas Pliocene sapropels have much higher sterol contents, up to $370.65 \mu \mathrm{g} / \mathrm{g}$ (Table $4)$. The Pleistocene-Pliocene trends of the organic-carbon-normalized concentrations of sterols are similar to those of the absolute concentrations, with values up to $1200 \mu \mathrm{g} / \mathrm{gC}$ (Table 4).

The wide range of sterols found in sapropels is typical of a marine system, and most of the major individual sterol components are common constituents of marine phytoplankton. The general compositional features of sterols are quite similar in all sapropel samples. However, differences in the relative abundance of the various components suggest variations in the composition of the contributing biological precursor communities. The organic-carbon-lean samples overlying and underlying sapropels contained very low amounts of only a few sterols without the diversity that commonly characterizes a productive marine system.

Cholesterol (cholest-5-en-3 $\beta$-ol) is very often the most abundant sterol encountered in environments with high marine-organic supply (high productivity; e.g., Gagosian et al., 1983) and is generally attributed to zooplankton or other marine fauna, because cholesterol constitutes the major sterol of most marine animals. This was not the case, however, in the sapropels, where cholesterol abundance is low relative to other sterols derived mainly from phytoplankton (phytosterols). High amounts of $\mathrm{C}_{28}$ sterols, namely brassicasterol (24methylcholesta-5,22-diene-3 $\beta$-ol) and 24-methylcholesta-5,24(28)diene- $3 \beta$-ol (and the corresponding stanols) were encountered in all sapropel samples. They are major constituents of many diatoms (Volkman, 1986) and have been used in numerous cases to trace such a source (e.g., Lee et al., 1980). Nevertheless, a number of Prymnesiophytes have also been found to produce brassicasterol as the principal sterol (Marlowe et al. 1984). The high amount of alkenones found in sapropels indicates that such algae may have contributed to the abundance of brassicasterol. Within the Pleistocene sapropels the variations of long-chain alkenone concentrations were smaller than the corresponding variations of the above sterols, which suggests diatoms as the main contributors of brassicasterol found in these samples. The diatom contribution appeared to be less important in sapropel S6 than in sapropels S5 and S7.

Very high concentrations of brassicasterol and the corresponding stanol were found in the two Pliocene sapropels investigated. Their profile is different from that of alkenones in sapropel A but very similar in sapropel B. This might indicate a prominent diatom source for these sterols in sapropel A and a mixed source (diatoms and prymnesiophytes) in sapropel B.

High amounts of dinosterol $(4 \alpha, 23,24$-trimethyl-5 $\alpha(\mathrm{H})$-cholesta$22 \mathrm{E}-\mathrm{ene}-3 \beta$-ol), were also found, accompanied by smaller amounts of other 4-methyl sterols. Their presence indicates that a significant proportion of the organic matter is derived from dinoflagellates (de Leeuw et al., 1983; Robinson et al., 1984). The absolute concentration, as well as the relative importance of dinosterols in the sapropels studied here, revealed dominant dinoflagellate inputs in two Pleistocene sapropels (S5 and S7) and in the older one of the two Pliocene sapropels. It is noteworthy, however, that Volkman et al. (1990) raised the possibility that poorly studied groups of microalgae may contain 4-methyl sterols.

Other sterols abundant in the samples include $\beta$-sitosterol (24-ethylcholest-5-ene-3 $\beta$-ol), stigmasterol (24-ethylcholesta-5,22E-diene$3 \beta$-ol), and campesterol (24-methylcholest-5-ene-3 $\beta$-ol), often accompanied by the corresponding stanols. These compounds are among the major sterols found in terrestrial plants (Goad and Goodwin, 1972). Sitosterol has been commonly used as a marker of terrigenous organic matter (e.g., Huang and Meinschein, 1976; Saliot et al., 1982), although its origin remained long uncertain since marine sources were also invoked to explain its major occurrence in environments where a terrestrial origin seemed unlikely (Volkman, 1986). 
Table 4. Summary of sterol data and concentrations of selected individual compounds.

\begin{tabular}{|c|c|c|c|c|c|c|c|c|c|c|c|c|c|c|c|}
\hline $\begin{array}{l}\text { Core, section, } \\
\text { interval }(\mathrm{cm})\end{array}$ & Sapropel & $\begin{array}{c}\text { Sterols } \\
(\mu \mathrm{g} / \mathrm{g})\end{array}$ & $\begin{array}{l}\text { Sterols } \\
(\mu \mathrm{g} / \mathrm{g} \mathrm{C})\end{array}$ & $\begin{array}{c}\text { Sterols } \\
\mathrm{C}_{27} \\
(\%)\end{array}$ & $\begin{array}{c}\text { Sterols } \\
\mathrm{C}_{28} \\
(\%)\end{array}$ & $\begin{array}{c}\text { Sterols } \\
\mathrm{C}_{29} \\
(\%)\end{array}$ & $\begin{array}{c}\text { 4-Me } \\
\text { Sterols } \\
(\%)\end{array}$ & $\begin{array}{c}\text { Cholesterol } \\
(\mu \mathrm{g} / \mathrm{g})\end{array}$ & $\begin{array}{c}\text { Cholestanol } \\
(\mu \mathrm{g} / \mathrm{g})\end{array}$ & $\begin{array}{l}\text { Brassicasterol } \\
(\mu \mathrm{g} / \mathrm{g})\end{array}$ & $\begin{array}{l}\text { Brassicastanol } \\
(\mu \mathrm{g} / \mathrm{g})\end{array}$ & $\begin{array}{c}\beta \text {-sitosterol } \\
(\mu \mathrm{g} / \mathrm{g})\end{array}$ & $\begin{array}{c}\beta \text {-sitostanol } \\
(\mu \mathrm{g} / \mathrm{g})\end{array}$ & $\begin{array}{l}\text { 1 Dinostero } \\
(\mu \mathrm{g} / \mathrm{g})\end{array}$ & $\begin{array}{r} \\
\text { ol Sitosterol/ } \\
\mathrm{C}_{29} \text { alkane }\end{array}$ \\
\hline $\begin{array}{l}\text { 160-969B- } \\
2 \mathrm{H}-1,38-40\end{array}$ & & 17.84 & 241.13 & 4.69 & 46.47 & 19.22 & 29.61 & 0.33 & 0.12 & 2.65 & 2.67 & 1.06 & 0.70 & 3.00 & 1.66 \\
\hline $\begin{array}{l}160-969 \mathrm{E}- \\
1 \mathrm{H}-3,87-89\end{array}$ & S5 & 24.18 & 331.24 & 4.76 & 29.18 & 30.23 & 35.83 & 0.62 & 0.53 & 2.89 & 0.57 & 1.68 & 1.81 & 4.43 & 2.42 \\
\hline $\begin{array}{l}2 \mathrm{H}-1,47-49 \\
2 \mathrm{H}-1,63-65\end{array}$ & S6 & $\begin{array}{l}3.05 \\
4.22\end{array}$ & $\begin{array}{l}105.11 \\
168.66\end{array}$ & $\begin{array}{r}8.38 \\
21.69\end{array}$ & $\begin{array}{l}33.73 \\
21.51\end{array}$ & $\begin{array}{l}47.54 \\
42.65\end{array}$ & $\begin{array}{r}8.35 \\
13.35\end{array}$ & $\begin{array}{l}0.12 \\
0.18\end{array}$ & $\begin{array}{l}0.05 \\
0.18\end{array}$ & $\begin{array}{l}0.19 \\
0.19\end{array}$ & $\begin{array}{l}0.07 \\
0.06\end{array}$ & $\begin{array}{l}0.36 \\
0.44\end{array}$ & $\begin{array}{l}0.11 \\
0.18\end{array}$ & $\begin{array}{l}0.11 \\
0.25\end{array}$ & $\begin{array}{l}0.20 \\
0.19\end{array}$ \\
\hline $\begin{array}{l}\text { 160-969B- } \\
2 \mathrm{H}-2,70-72 \\
\end{array}$ & So & 4.24 & 136.79 & 19.23 & 20.85 & 51.90 & 6.99 & 0.32 & 0.32 & 0.53 & 0.09 & - & 0.25 & 0.30 & 0.47 \\
\hline $\begin{array}{l}160-969 \mathrm{E}- \\
2 \mathrm{H}-2,128-130\end{array}$ & S7 & 14.74 & 267.94 & 4.89 & 19.93 & 34.50 & 40.68 & 0.27 & 0.15 & 0.73 & 0.24 & 1.02 & 0.59 & 4.46 & 0.62 \\
\hline $\begin{array}{c}160-969 \mathrm{~B}- \\
7 \mathrm{H}-1,94-95 \\
7 \mathrm{H}-1,99-100 \\
7 \mathrm{H}-1,102-103 \\
7 \mathrm{H}-1,105-106 \\
7 \mathrm{H}-1,109-110 \\
\end{array}$ & Sapropel & $\begin{array}{r}0.21 \\
51.11 \\
175.77 \\
34.31 \\
0.60\end{array}$ & $\begin{array}{r}129.09 \\
309.75 \\
1290.56 \\
377.05 \\
400.00 \\
\end{array}$ & $\begin{array}{r}45.61 \\
5.59 \\
5.76 \\
10.33 \\
89.81 \\
\end{array}$ & $\begin{array}{r}49.12 \\
49.59 \\
53.24 \\
38.67 \\
7.55 \\
\end{array}$ & $\begin{array}{r}0.00 \\
32.56 \\
27.44 \\
31.75 \\
0.00 \\
\end{array}$ & $\begin{array}{r}5.27 \\
12.26 \\
13.56 \\
19.26 \\
2.10 \\
\end{array}$ & $\begin{array}{l}0.08 \\
1.19 \\
4.56 \\
1.85 \\
0.54\end{array}$ & $\begin{array}{c}0.01 \\
1.23 \\
4.49 \\
0.59 \\
\text { TR }\end{array}$ & $\begin{array}{r}0.03 \\
7.73 \\
29.45 \\
5.32 \\
\text { TR }\end{array}$ & \begin{tabular}{r}
\multicolumn{1}{c}{ TR } \\
11.32 \\
27.42 \\
0.31 \\
0.02 \\
\end{tabular} & $\begin{array}{c}\text { TR } \\
1.64 \\
11.04 \\
5.90 \\
\text { TR } \\
\end{array}$ & $\begin{array}{c}\text { TR } \\
4.11 \\
13.27 \\
\text { TR } \\
\text { TR } \\
\end{array}$ & $\begin{array}{r}0.01 \\
3.84 \\
10.50 \\
2.88 \\
0.01 \\
\end{array}$ & $\begin{array}{r}0.17 \\
2.60 \\
11.62 \\
3.24 \\
- \\
\end{array}$ \\
\hline $\begin{array}{l}7 \mathrm{H}-2,68-70 \\
7 \mathrm{H}-2,75-76 \\
7 \mathrm{H}-2,80-81 \\
7 \mathrm{H}-2,83-84 \\
7 \mathrm{H}-2,85-86 \\
7 \mathrm{H}-2,88-89 \\
7 \mathrm{H}-2,90-91 \\
7 \mathrm{H}-2,94-95\end{array}$ & $\begin{array}{c}\text { Sapropel } \\
\text { B }\end{array}$ & $\begin{array}{r}0.21 \\
17.58 \\
237.19 \\
370.65 \\
339.87 \\
265.02 \\
15.25 \\
0.25\end{array}$ & $\begin{array}{r}123.53 \\
976.41 \\
1093.03 \\
1151.08 \\
1200.94 \\
967.23 \\
171.35 \\
130.63\end{array}$ & $\begin{array}{r}11.23 \\
4.62 \\
8.76 \\
12.44 \\
9.08 \\
10.89 \\
7.35 \\
7.11\end{array}$ & \begin{tabular}{r|}
26.56 \\
47.71 \\
34.00 \\
25.98 \\
30.32 \\
31.63 \\
31.07 \\
7.86
\end{tabular} & $\begin{array}{l}37.87 \\
28.07 \\
32.29 \\
39.70 \\
37.36 \\
35.59 \\
34.82 \\
33.06\end{array}$ & $\begin{array}{l}24.34 \\
19.60 \\
24.81 \\
21.88 \\
23.24 \\
21.89 \\
26.76 \\
51.96\end{array}$ & $\begin{array}{c}0.04 \\
0.34 \\
6.01 \\
5.15 \\
10.34 \\
4.852 \\
0.48 \\
0.01\end{array}$ & $\begin{array}{r}\text { TR } \\
0.29 \\
9.61 \\
31.86 \\
18.15 \\
2.86 \\
0.35 \\
0.01\end{array}$ & \begin{tabular}{r|}
0.02 \\
0.79 \\
15.83 \\
18.98 \\
28.49 \\
16.34 \\
1.19 \\
0.01
\end{tabular} & \begin{tabular}{r|}
\multicolumn{1}{c}{ TR } \\
0.15 \\
8.65 \\
26.86 \\
15.75 \\
18.50 \\
0.20 \\
0.01
\end{tabular} & \begin{tabular}{r|}
0.09 \\
1.47 \\
22.10 \\
37.45 \\
36.04 \\
26.19 \\
1.35 \\
0.02
\end{tabular} & $\begin{array}{r}0.07 \\
1.41 \\
22.29 \\
49.65 \\
37.28 \\
31.59 \\
1.23 \\
0.02\end{array}$ & $\begin{array}{r}0.07 \\
2.74 \\
37.94 \\
48.22 \\
53.55 \\
37.08 \\
1.88 \\
0.10\end{array}$ & $\begin{array}{l}0.97 \\
1.44 \\
3.17 \\
2.35 \\
4.40 \\
3.45 \\
1.18 \\
0.05\end{array}$ \\
\hline
\end{tabular}

Note: $\mathrm{TR}=$ traces.

Several species of phytoplankton have been found to contain significant amounts of 24-ethylcholesterol, such as Prymnesiophytes (Volkman et al., 1990) or cyanobacteria (Boon et al., 1983). Similar uncertainties exist for the other sterols that are commonly considered terrestrial (Volkman, 1986, and references therein).

In the sapropel samples studied here, both terrestrial and marine organic matter sources have been recognized using biomarkers other than sterols. Consequently, sitosterol, stigmasterol, and campesterol are most likely of mixed origin. A useful approach to determine the most important origin of these sterols is to compare the 24-ethylcholesterol profile with that of a typical terrestrial marker from another lipid class, such as the $n-\mathrm{C}_{29}$ alkane. This comparison within the two Pliocene sapropels shows that although the variations of the considered compounds have similar trends, the increase in the $n-\mathrm{C}_{29}$ concentration is much more important than that of the $\mathrm{C}_{29}$-sterol (the ratio $\mathrm{C}_{29}$-sterol/ $\mathrm{C}_{29}$ alkane increases). This may indicate that 24-ethylcholesterol from marine sources is more important, at least in samples where highest organic carbon contents are encountered.

Along with the nuclear unsaturated stenols discussed above, several $5 \alpha(\mathrm{H})$-stanols were also found in high concentrations, which in many cases were higher than those of the unsaturated counterparts. Stanols can be formed by bacterial reduction of sterols (Smith et al., 1983), and some authors have suggested that the stenol to stanol transformation reaction rate increases as the redox potential decreases (e.g., Nishimura and Koyama, 1977). In the Black Sea, however, the stenol/stanol ratio appeared to be determined primarily by varying contributions from specific source-organisms than by a chemical or bacterial conversion (Gagosian and Heinzer, 1979). Dinoflagellates have been recognized as the major specific source of $5 \alpha(\mathrm{H})$ stanols in sediments (Robinson et al., 1984). In the present case, a tendency for the proportion of stanols to increase and to become even more abundant than stenols was observed within the two Pliocene sapropels. This could be interpreted as an indication of enhanced stenol to stanol conversion under anoxic conditions. Nevertheless, the sterol data clearly showed that dinoflagellate contributions are very important and, consequently, they most likely contributed to the stanols.

\section{Marine vs. Terrestrial Organic Matter Sources}

The major lipid classes examined here indicate the presence of both terrigenous and marine organic matter in the sapropels. Important terrestrial higher plant material was largely represented in the long-chain $n$-alcohol and $n$-alkane abundances and compositional features. High marine organic matter contributions have been recognized by the presence of large amounts of alkandiols and alkanolones, alkenones, and sterols, although within the latter lipid class terrestrial sources have most likely contributed as well. A comparison of the summed concentrations of marine and terrestrial lipids leads to the statement that organic matter in sapropels is predominantly of marine origin. However, one should be cautious when interpreting absolute concentrations of biomarker compounds in terms of source abundance, because the ratio of a source-specific biomarker vs. the associated organic matter in the original biota remains largely unknown, as does the modification of this ratio by diagenesis.

All the major lipid classes reported here, both marine and terrestrial, show very significant correlation with the organic-carbon content $(\mathrm{R}>0.95)$, which clearly indicates that both contributions have increased with increasing accumulation of organic carbon. However, these relationships can not attest to the predominant origin of the organic matter in sapropels. The distribution of the various lipids within the series of samples taken through the two Pliocene sapropels and in the oxidized sedimentary sequences overlying and underlying them could help to unveil this issue.

Absolute concentrations of the typical terrestrial lipids, such as the long-chain $n$-alkanes and $n$-alcohols, show a distribution that closely parallels that of the organic carbon (Fig. 4). This strongly suggests a link between increased terrestrial supply and sapropel formation. A terrestrial supply may have occurred through increased river discharge and/or increased continental run-off from the Mediterranean borderlands as previously proposed (Rossignol-Strick, 1985; Rohling and Hilgen, 1991). When examining the organic-carbonnormalized concentrations of lipids, however, it can be noticed that the terrestrial contribution to the organic matter within sapropels shows little variation and is considerably lower than that observed in 

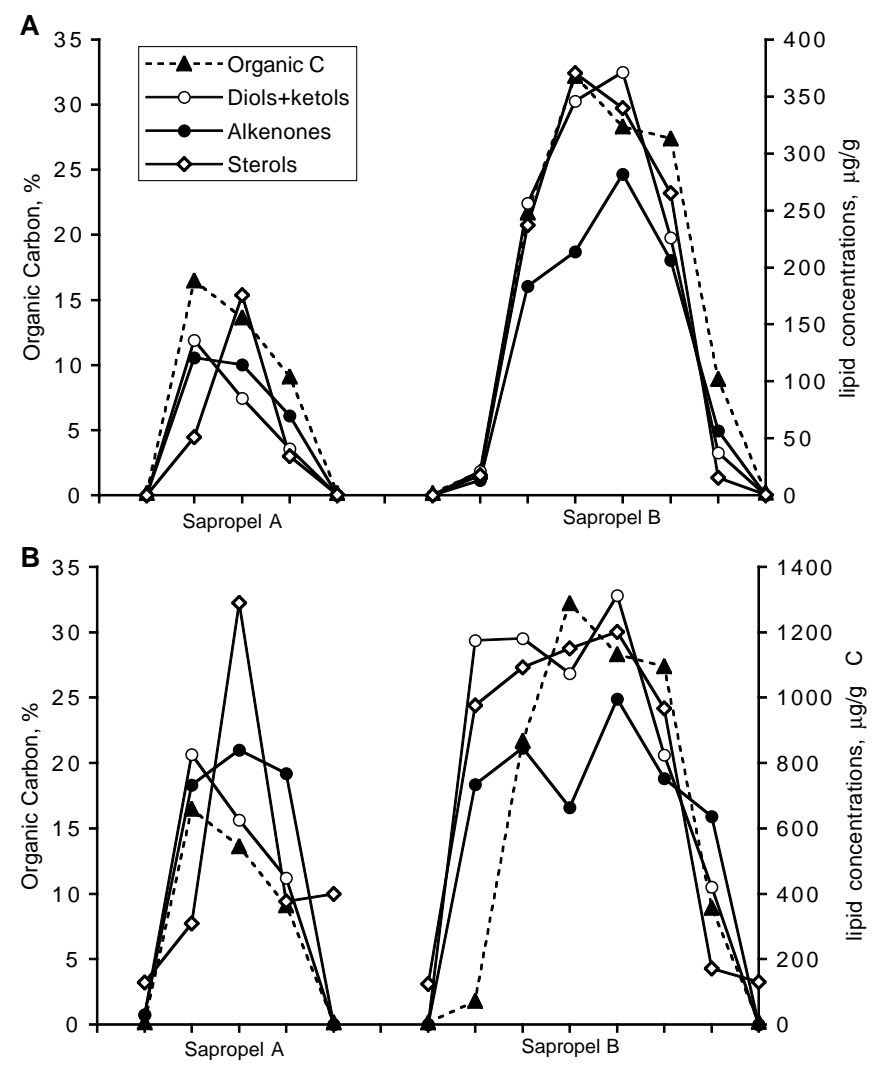

Figure 5. Distribution of marine lipids within the two Pliocene sapropels. A. Profile of absolute concentrations ( $\mu \mathrm{g} / \mathrm{g}$ of sediment). B. Profile of organiccarbon-normalized concentrations ( $\mu \mathrm{g} / \mathrm{g}$ of organic carbon).

the organic-carbon-lean samples (Fig. 4). This suggests that although supply of terrestrial organic matter strongly increased during times of sapropel deposition, this terrigenous organic matter most likely does not account for the main portion of the accumulated organic matter, as opposed to the case of the nonsapropel samples, where terrestrial contributions appear to dominate.

Similar observations can be made with regard to the distribution of the absolute concentrations of lipids from marine sources, thus, providing evidence for increased phytoplanktonic supply during times of sapropel formation (Fig. 5). The contribution of marinederived lipids to the organic carbon shows a steep increase within the sapropels, with drops (with one exception) in nonsapropel samples (Fig. 5). This contrasts with the behavior of terrestrial lipids and argues that as the accumulation of organic matter increases, the relative contributions from marine sources become larger. The carbon-normalized concentrations of sterols in nonsapropel samples show values higher than those of other marine lipids, suggesting either the occurrence of small specific marine contributions or better preservation of sterols under oxic conditions. Slight differences in the distribution profiles of the marine lipids (Fig. 5) most likely represent differences in the relative abundance of their biological precursors. For example, long-chain alkenones (as carbon-normalized concentrations), and consequently Prymnesiophytes, appear to predominate in the first stage of sapropel formation, which contrasts with the other marine lipids (Fig. 5).

\section{CONCLUSIONS}

Molecular compositions of the free lipid classes provide valuable information with respect to their biological sources, and thus allow assessment of dominant contributions to the organic matter in the sapropels.

The composition of sapropel lipids, and their comparison with lipids in nonsapropel samples clearly indicate that organic matter in sapropels derives predominantly from marine planktonic sources. Marine contributions increase with increasing carbon accumulation, suggesting enhanced supply of planktonic material to the sediments during sapropel formation. Nevertheless, large amounts of terrestrial contributions were recognized as well. Sapropel formation appears to coincide with a substantial increase in terrestrial supply.

The lipids investigated are well preserved, but further study is needed to assess the extent and role of anoxia in the preservation of organic matter in the sapropels. Furthermore, on-going studies coupling molecular and isotopic approaches, as well as a comparison with independent proxies, would better constrain the sources of organic matter in the sapropels and the major mechanisms leading to the sapropel formation.

\section{ACKNOWLEDGMENTS}

The postcruise study was supported by the French National Program "Geosciences Marines." This paper benefited from reviews from R. Stax and P. Meyers. Special thanks to E. Stephanou and A. Gogou (University of Crete) for providing GC/MS facilities and assistance.

\section{REFERENCES}

Blumer, M., Guillard, R.R.L., and Chase, T., 1971. Hydrocarbons of marine phytoplankton. Mar. Biol., 8:183-189.

Boon, J.J., Hines, H., Burlingame, A.L., Klock, J., Rijpstra, W.I.C., de Leeuw, J.W., Edmunds, K.E., and Eglinton, G., 1983. Organic geochemical studies of Solar Lake laminated cyanobacterial mats. In Bjoroy, et al. (Eds.), Advances in Organic Geochemistry 1981, 239-248.

Boon, J.J., van der Meer, F.W., Schuyl, P.J.W., de Leeuw, J.W., Schenck, P.A., and Burlingame, A.L., 1978. Organic geochemical analyses of core samples from Site 362, Walvis Ridge, DSDP Leg 40. In Bolli, H.M., Ryan, W.B.F., et al., Init. Repts. DSDP, 40 (Suppl.): Washington (U.S. Govt. Printing Office), 627-637.

Brassell, S.C., 1993. Applications of biomarkers for delineating marine paleoclimatic fluctuations during the Pleistocene. In Engel, M.H., and Macko, S.A. (Eds.), Organic Geochemistry: Principles and Applications: New York (Plenum), 699-738.

Calvert, S.E., 1983. Geochemistry of Pleistocene sapropels and associated sediments from the Eastern Mediterranean. Oceanol. Acta, 6:225-267.

De Lange, G.J., and ten Haven, H.L., 1983. Recent sapropel formation in the Eastern Mediterranean. Nature, 305:797-798.

de Leeuw, J.W., Rijpstra, W.I.C., and Mur, L.R., 1992. The absence of longchain alkyl diols and alkyl keto-1-ols in cultures of the cyanobacterium Aphanizomenon flos-aquae. Org. Geochem., 18:575-578.

de Leeuw, J.W., Rijpstra, W.I.C., and Schenck, P.A., 1981. The occurrence and identification of $\mathrm{C}_{30}, \mathrm{C}_{31}$ and $\mathrm{C}_{32}$ alkan-1,15-diols and alkan-15-one1-ols in Unit I and Unit II Black Sea sediments. Geochim. Cosmochim. Acta, 45:2281-2285.

de Leeuw, J.W., Rijpstra, W.I.C., Schenck, P.A., and Volkman, J.K., 1983. Free, esterified, and residual bound sterols in Black Sea Unit I sediments. Geochim. Cosmochim. Acta, 47:455-465.

Eglinton, G., and Hamilton, R.J., 1967. Leaf epicuticular waxes. Science, 156:1322-1335.

Gagosian, R.B., and Heinzer, F., 1979. Stenols and stanols in the oxix and anoxic waters of the Black Sea. Geochim. Cosmochim. Acta, 43:471486.

Gagosian, R.B., Volkman, J.K., and Nigrelli, G.E., 1983. The use of sediment traps to determine sterol sources in coastal sediments off Peru. In Bjoroy, M. (Ed.), Advances in Organic Geochemistry, 1981: Chichester (Wiley), 369-379.

Gaskell, S.J., Morris, R.J., Eglinton, G., and Calvert, S.E., 1975. The geochemistry of a recent marine sediment off north-west Africa -an assessment of source of input and early diagenesis. Deep-Sea Res., 22:777-789. 
Goad, L.J., and Goodwin, T.W., 1972. The biosynthesis of plant sterols. Prog. Phytochem., 20:1935-1937.

Huang, W.Y., and Meinschein, W.G., 1976. Sterols as source indicators of organic materials in sediments. Geochim. Cosmochim. Acta, 40:323-330.

Lee, C., Gagosian, R.B., and Farrington, J.W., 1980. Geochemistry of sterols in sediments from the Black Sea and the southwest African Shelf and slope. Org. Geochem., 2:103-113.

Marlowe, I.T., Brassell, S.C., Eglinton, G., and Green, J.C., 1990. Longchain alkenones and alkyl alkenoates and the fossil coccolith record of marine sediments. Chem. Geol., 88:349-375.

Marlowe, I.T., Green, J.C., Neal, A.C., Brassell, S.C., Eglinton, G., and Course, P.A., 1984. Long chain (n-C37-C39) alkenones in the Prymnesiophyceae: distribution of alkenones and other lipids and their taxonomic significance. Br. Phycol. J., 19:203-216.

Morris, R.J., and Brassell, S.C., 1988. Long-chain alkanediols: biological markers of cyanobacteria in sediments. Lipids, 23:256-258.

Müller, P.J., and Suess, E., 1979. Productivity, sedimentation rate, and sedimentary organic matter in the oceans, I. Organic carbon preservation. Deep-Sea Res. Part A, 26:1347-1362.

Nishimura, M., and Koyama, T., 1977. The occurrence of stanols in various living organisms and the behaviour of sterols in contemporary sediments. Geochim. Cosmochim. Acta, 41:379-385.

Pedersen, T.F., and Calvert, S.E., 1990. Anoxia vs. productivity: what controls the formation of organic-carbon-rich sediments and sedimentary rocks? AAPG Bull., 74:454-466.

Requejo, A.G., Quinn, J.G., Gearing, J.N., and Gearing, P.J., 1984. $\mathrm{C}_{25}$ and $\mathrm{C}_{30}$ biogenic alkenes in a sediment from the upper anoxic basin of the Pettaquamscutt River (Rhode Island, U.S.A.). Org. Geochem., 7:1-10.

Robinson, N., Eglinton, G., Brassell, S.C., and Cranwell, P.A., 1984. Dinoflagellate origin for sedimentary $4 \alpha$-methylsteroids and $5 \alpha(\mathrm{H})$ stanols. Nature, 308:439-441.

Rohling, E.J., 1994. Review and new aspects concerning the formation of eastern Mediterranean sapropels. Mar. Geol., 122:1-28.

Rohling, E.J., and Hilgen, F.J., 1991. The eastern Mediterranean climate at times of sapropel formation: a review. Geol. Mijnbouw, 70:253-264.

Rossignol-Strick, M., 1985. Mediterranean Quaternary sapropels, an immediate response of the African Monsoon to variation of insolation. Palaeogeogr., Palaeoclimatol., Palaeoecol., 49:237-263.

Rowland, S.J., and Robson, J.N., 1990. The widespread occurrence of highly branched acyclic C20, C25 and C30 hydrocarbons in recent sediments and biota: a review. Mar. Environ. Res., 30:191-206.

Saliot, A., Goutx, M., Fevrier, A., Tusseau, D., and Andrie, C., 1982. Organic sedimentation in the Arabian Sea: relationship between the lipid composition of small- and large-size, surface and deep particles. Mar. Chem., 11:257-278.

Sargent, J.R., Gatten, R.R., and Henderson, R.J., 1981. Marine wax esters. Pure Appl. Chem., 53:867-871.

Shipboard Scientific Party, 1996. Site 969. In Emeis, K.-C., Robertson, A.H.F., Richter, C., et al., Proc. ODP, Init. Repts., 160: College Station, TX (Ocean Drilling Program), 335-375.

Smith, D.J., Eglinton, G., and Morris, R.J., 1986. The lipid geochemistry of a recent sapropel and associated sediments from the Hellenic Outer Ridge, eastern Mediterranean Sea. Philos. Trans. R. Soc. London A, 319:375419.

Smith, D.J., Eglinton, G., Morris, R.J., and Poutanen E.L., 1983. Aspects of the steroid geochemistry of a recent diatomaceous sediment from the Namibian shelf. Oceanol. Acta, 5:365-378.

Stephanou, E., and Stratigakis, E., 1993. Determination of anthropogenic and biogenic organic compounds on airborne particles: flash chromatographic fractionation and capillary gas chromatographic analysis. $J$. Chromatog., 644:141-151.

ten Haven, H.L., Baas, M., de Leeuw, J.W., and Schenck, P.A., 1987. Late Quaternary Mediterranean sapropels, I. On the origin of organic matter in sapropel $\mathrm{S}_{7}$. Mar. Geol., 75:137-156.

Thierstein, H.R., Geitzenauer, K., Molfino, B., and Shackleton, N.J., 1977. Global synchroneity of late Quaternary coccolith datum levels: validation by oxygen isotopes. Geology, 5:400-404.

Thunell, R.C., Williams, D.F., and Belyea, P.R., 1984. Anoxic events in the Mediterranean Sea in relation to the evolution of late Neogene climates. Mar. Geol., 59:105-134.

Venkatesan, M.I., 1988. Organic geochemistry of marine sediments in Antarctic region: marine lipids in McMurdo Sound. Org. Geochem., 12:1327.

Vergnaud-Grazzini, C., Devaux, M., and Znaidi, J., 1986. Stable isotope "anomalies" in Mediterranean Pleistocene records. Mar. Micropaleontol., 10:35-69.

Volkman, J.K., 1986. A review of sterol markers for marine and terrigenous organic matter. Org. Geochem., 9:83-99.

Volkman, J.K., Barrett, S.M., and Dunstan, G.A., 1984. $\mathrm{C}_{25}$ and $\mathrm{C}_{30}$ highly branched isoprenoid alkenes in laboratory cultures of two marine diatoms. Org. Geochem., 21:407-413.

Volkman, J.K., Barrett, S.M., Dunstan, G.A., and Jeffrey, S.W., 1992. C ${ }_{30}-$ $\mathrm{C}_{32}$ alkyl diols and unsaturated alcohols in microalgae of the class Eustigmatophyceae. Org. Geochem., 18:131-138.

Volkman, J.K., Eglinton, G., Corner, E.D.S., and Sargent, J.R., 1980. Novel unsaturated straight-chain $\mathrm{C}_{37}-\mathrm{C}_{39}$ methyl and ethyl ketones in marine sediments and a coccolithophore Emiliania huxleyi. In Douglas, A.G., and Maxwell, J.R. (Eds.), Advances in Organic Geochemistry 1979: Oxford (Pergamon Press), 219-228.

Volkman, J.K., Farrington, J.W., Gagosian, R.B., and Wakeham, S.G., 1983. Lipid composition of coastal marine sediments from the Peru upwelling region. In Bjoroy, et al. (Eds.), Advances in Organic Geochemistry 1981, $228-240$.

Volkman, J.K., Kearney, P., and Jeffrey, S.W., 1990. A new source of 4methyl sterols and $5 \mathrm{a}(\mathrm{H})$-stanols in sediments: prymnesiophyte microalgae of the genus Pavlova. Org. Geochem., 15:489-497.

Date of initial receipt: 3 February 1997

Date of acceptance: 26 June 1997

Ms 160SR-003 